\title{
Mechanized education
}

\author{
Isabel E. Rojas Castillo
}

Facultad de Humanidades, Universidad de San Carlos de Guatemala, Guatemala

*Autora a la que se dirige la correspondencia: isabellarojascastillo@gmail.com

\section{Resumen}

$\mathrm{P}$ or educación mecanizada se entiende al conjunto de procesos establecidos, que lejos están de ser adecuados a los contextos reales de aprendizaje y limitan la capacidad natural del ser humano. El propósito fundamental de la investigación es promover cambios en los entornos educativos, donde el aprendizaje ha sido condicionado hasta inhibir la capacidad a procesos mecánicos. Ante la crisis que enfrenta el sistema educativo, se proyecta reflexionar sobre la situación actual de emergentes comunes y proponer acciones futuras, para alcanzar los objetivos de la educación en una nueva era. El cambio va más allá de la implementación de tecnología, es modificar las prácticas de enseñanza y aprendizaje.La metodología en esta investigación documental, se validó en el análisis bibliográfico de la teoría de Michel Foucault, a través de la síntesis, deducción y reflexión de elementos propios del campo de la sociología y pedagogía, para reunir una crítica orientada a reconocer el ejercicio del poder en las cárceles, y la imitación de esos factores en el contexto escolarizado; así comprender los actuales ambientes de aprendizaje.Los resultados evidencian una formación académica con modelos tradicionales y de enseñanza individualizada, lo cual permite un replanteamiento de la formación escolar. Para transformarlo se propone la técnica de instrucción por pares y el modelo de clase invertida hacia un aprendizaje colaborativo.En conclusión, se ofrece una reflexión para las organizaciones educativas, al confrontar que el ejercicio de poder y control debe existir, pero sin intentar homogenizar las capacidades innatas del ser humano.

Palabras claves: educando, tradicional, homogenizar, aprendizaje, colaborativo

\section{Abstract}

$\mathrm{M}$ echanized felling, education is understood as the set of processes, which are far from adequate to the real contexts of learning and limit the natural capacity of the human being. The fundamental purpose of the research is to promote changes in educational environments, where learning has been conditioned to inhibit the ability to mechanical processes.Before the crisis facing the education system, it is planned to reflect on the current state of emerging common and propose future actions to achieve the goals of education in a new era. The change goes beyond the implementation of technology, is to change the teaching and learning practices. The methodology in this documentary research, is valid in the bibliographic analysis of the theory of Michel Foucault, through the synthesis, deduction and reflection of elements of the field of sociology and pedagogy, to gather a critical oriented to recognize the exercise of power in prisons, and the imitation of these factors in the context of school. To understand the current learning environments. The results show an academic training with traditional models and individualized education. which allows for a rethinking of the school. To transform it, it is proposed that the technique of Peer Instruction and the Flipped Classroom model, toward collaborative learning.In conclusion, it is a reflection for educational organizations and confront the fact that the exercise of power and control must exist, but without trying to homogenize the innate abilities of the human being.

Key words: educating, traditional, homogenize, learning, collaborative. 